\title{
84 the true aerialist (the angel in the house)
}

\author{
Barbara Bridger
}

The True Aerialist demonstrates some of the risks inherent for women in any moment of performance. It does this through a series of contradictions that begin with the True Aerialist's claim to be a liar. When she goes on to reject various conventional 'props' of performance - narrative, dialogue, subtext, characterization and pretence in favour of clowning and spectacle, the True Aerialist enacts a brave, defiant and transgressive alternative strategy.

This is a shortened version of the original script for live performance. The full text owes much to my work with devised, improvised, physical theatre. This prose version omits the many stage directions, which describe the considerable physical challenge facing any woman performing The True Aerialist. 


\section{THE TRUE AERIALIST}

\section{Subtitled}

THE ANGEL IN THE HOUSE

A WOMAN DRESSED IN AN ECLECTIC RANGE OF STYLES CROSSES THE SPACE CASTING ONE FURIOUS SIDEWAYS GLANCE AT THE AUDIENCE BEFORE EXITING. THE SAME WOMAN REENTERS AND REPEATS HER ACTIONS. THE SAME WOMAN RE-ENTERS A THIRD TIME, STOPS MID-SPACE AND TAKES UP A JABBING, POINTING ACTION AIMED AT THE AUDIENCE. AFTER A SECOND OR TWO HER FINGER BECOMES OUT OF CONTROL AND TURNS TOWARDS HER MAKING FOR HER MOUTH AND FORCING ITSELF DOWN HER THROAT, CHOKING OUT HER FIRST WORDS

I...... I lie....

CLAMPS RIGHT HAND OVER MOUTH. REMOVES IT WITH DIFFICULTY USING OTHER HAND.

....constantly. I deceive.... perpetually. I conceal what I see and I pretend what I am.

Believe me, please believe me - you can't. Because nothing about me is true. Even this voice is false; it's merely an echo, a fals...etto. So do not

count on my ethnic origin. It reveals nothing of my date of birth. My tongue, my mother tongue: ma madonnaish tangen says nothing. Absolutischen null. But a mother tongue has gender at least, whereas I - what am I? Mutable? Transverse perhaps? What do you think? Have a guess. Go on, do us a favour. Left or right? In or out? Back to front? What's it to be? $50 / 50$ ? $30 / 70$ ? 100 to one?

Whatever you think you're wrong. Wrong, wrong, wrong.

I'm unclassifiable. The class of my arse changes all the time. You can't rely on it. Some days I can't even sit on it. But on such days, on such sweet spring days, when the dew gathers on my fingertips. On such fine, blue days I can...always.... fly.

Like 'em? They're all mine, my own wings. 
Oh yes, I can assure you there's no artifice here. Some glue perhaps and I'm no angel, but that's another matter. The shaft of my feathers is my own affair..... entirely. And don't jump to conclusions, I wear my knickers on my head for good reason. I fly by the seat of my pants, on a wing and a prayer. So wish me luck, because you never know.... Christ you never know! (Superstition being the enemy of belief.) Yes, you never know when you might come up on the lottery. So, I'll buy a ticket. And if you see me there, praying in my lottery booth - my twentieth century confessional - remember this: I'm hooked...hooked on flying, on swooping up and down, on wheeling about. Watch me, watch me. Here I come again. Look out! Duck! Whee! And up

Oh, this is marvellous, inspirational. The sky is radiant, I fly, a silver meteor in its twinkling blueness. I fly, a stainless shard piercing the velvet of night. I fly a mote of mercury beading the crested ocean. I fly...

What's the matter? Oh come on, it's allowed - a little lyricism, a little lyric, a moment of romance - surely it's allowed? You can't deny poetry: my soul in verse, a version of my soul, subversion of your soul, through my...art! You can't deny me that imagining. Imagination being art......some say.

Look at me, I am a star, I am a star, I am a star, I am above it all, above you all. An artiste of the air, full of wind and piss, spraying you from a great height. Look at me. Just look at me. I'm good aren't I? Terrific. I'm... what? What was that? Have I got a what? No, no I haven't, no... no wing licence. I didn't think.... Really? Well, sorry, but I have no artistic licence for my superior state. In fact, steady on, oh hell, oh no... I can't...Ah shit! It's like one of those dreams - you're flying quite happily, superiorly in fact and then.... you suddenly realise.....but just a minute, regulations aren't everything. Oh ho, no ho! You can 
buck the system. Fight the bureaucracy. You can stop hanging about and....and..... and....LOOK OUT!!!

Sorry - really - very sorry, I'Il just keep quiet now. I'Il just hang loose. All that struggle was a mistake. I was carried away, taken for a ride. I was strung along. Puppetry has a lot to answer for. Talk about suspension of belief. It's asking a lot of a liar like me. So I'll shut up, because there's a real danger I could get hung up here - lynched for my upward mobility. To think...has it come to this? Has it? Now I know how Tinkerbell felt. It isn't fair, no, liar that I am, stuck up as I may be, I don't deserve this. I mean who doesn't have aspirations? Who doesn't want to go up in life? For this I should be so lampooned? To find my higher ambitions so bureaucratically bruised, so irretrievably damaged, well, it's hard to cope with. I.... I wonder.... could I have that feather back? It does suit you too, yes, there's no denying that, but I feel the lack: a failing follicle cannot be finally ignored. Thank you. I am grateful.

But to be honest, which as you know I never am, I was never a real flyer. No head for heights you see; not enough levity in my thoughts. I lack confidence. I can't ride a bicycle or swim. Yes, on many counts my expectation of levitation was unrealistic. Given my many shortcomings. But...well it's a tendency I have. Despite all, I tend to the unreal. I am subject to flights of fantasy. I get above myself. I put myself in a vertiginous position, like this, quite often. Then when I find the oxygen is thin...

Better to have my feet on the ground. Yes, I'm coming down, I've pressed the descend button. Here I come. That's it. A little bump and out at ground level. Back to scrambling down on the street, nose to the grindstone, shoulder to the wheel, hands to the plough, eyes on the ball. Back to getting in touch with reality, with work. Real life, real 
work, real, honest to goodness, made with natural ingredients, at the kitchen sink, tell it like it is. Let mine be a true story. A real story. Starting here, now.

'And the earth was waste and void; and darkness was upon the face of the deep: and the spirit of god moved upon the face of the waters.'

I'm so pregnant with possibility now they won't hang me. No, you can't get strung up in this state. I'm safe until after the birth of my beginning. Ah my sweet beginning, my little offspring. Here look, let me show you my egg, look there, isn't it perfect? A perfect beginning. I'm so proud I.... oh whoops! Silly me. What a mess on the floor. Oh well, another false start, but I'll tell you anyway:

Once upon a time, long ago, as I've heard tell, there was, as there might well be... Are you sitting comfortably? Quite sure? Then I'll begin. There was once a story, a narrative no less. And it was huge, essential, overarching and predictable and we all looked up to it. We looked up to it for so long we got a crick in our necks, but still we craned our eyes skywards saying things like: 'Hey is that a rainbow up there?

Well no it isn't I'm afraid, it's just a trick of the light. A trick, a story that no one believes in any more. Because no one believes in nothing. Except the lottery. And let's face it, two minuses don't make a plus, even to a two faced liar like me. It doesn't make sense and in the end, when you get past the prologue and the heart of the matter and you finally arrive at the epilogue, all I know is, first there was eggs and then there was a mistake.

So I ask myself,

Who made this bloody mess and who's going to clear it up?

I'm not.

Why not?

Because it's not my turn.

Why not?

You just said that.

So what?

So now it's your turn.

What?

Your turn to clear up

Why?

Because you spoke first. 
Did I?

Yes.

So?

So I've got the last word.

So?

So the last word is you've got to clear up

Well I won't...... I said I won't. That was the last word. I said the last word. Are you listening? Are you there? Is there anybody....?'

Oh no! What am I doing? What am I saying? You see what happens when you take a beginning, an egg for instance. You get plot, then you get dialogue, talk, conversation, chit chat, words and more words until you've got verbal diarrhoea, until you're sick with it. First there were eggs and then there was mess, followed by salmonella. But I'm not going to clear it up I'm not going to cook up this story because I told you, I don't believe in it anymore.

I believe...I believe...I believe... in... in the lottery... and....and then? And then? And then nothing, no birth, no death, no heaven, no re-incarnation, no over the rainbow, just.... just...supermarkets? We all believe in supermarkets. We believe in prayer within the sacred aisles.

Oh god please give me bargains.

On which to spend my winnings.

That I may profit from my greed.

I believe in spends. How much is that? I'll have it - give it me. I want one. I want two. I want them all, I need them all. I must eat after all. A conglomerate must be fed, supplied with the choicest ingredients - no rotten apples - no maggoty veg. Gimme- gimme - some - I want - gimme. I must eat, I must, or.... or die, or wilt and wither, or rot and decay, fester, fall into filth, turn into tilth. Let me eat so I can germinate - a sweet curled budding, a milk veined shoot. Let me eat, eat, grow, grow, move, shift. No moss, no sweet rotting, no fullness of time fermentation, no rich matter, no mulch, eat, eat, grow, grow, move shift. I 
want to grow, I want to grow, I want to grow...organically. It is the healthiest way after all. The only way you can count on. Can I start now? Thank you. One, two, three, four, seventy-six. No? Alright, five. What's wrong with five? Nothing? OK, try eleven then. Eleven? I don't know why. It's random. Completely. A creative calculation, a spiritual speculation. But...oh eleven...please! Alright, nineteen. Nineteen because it's my birthday, yes the nineteenth and I am growing.... up! And my playing...is getting chronic, inappropriate for someone my age. I'm beginning to wonder what it means.

Ow! Why did you do that? Ooof! Why are you hitting me? Aah! That hurts. What does this mean? Owowow! For pity's sake. I didn't really mean it. Not for a moment. To save any more mindless violence let me assure you that meaning means nothing to me. My content is uncontentious. My sub-text is completely subjugated. I do not mean anything. Try to believe that I lie emphatically, that I deceive..... thematically. I lie, I lie. I lie. It is in my nature. No please, don't hit me for that. I may have nature but look here at my wings. I am also artifice. I didn't grow them. My playing may be chronic but it's also serious. It's objective.

Objective. Yes, you can't object to that. The object...the object as opposed to the subject. As opposed to me. Leave me alone for a minute will you, and take a look at that, at this, at that. What does that say to you? Not about me. This is independent of me. That isn't mine. I don't own it. But then I never did. Oh I kidded myself but...looking back. I can see.... well, there was a time when I truly desired this beautiful object. I was enchanted by its colour: viridian of deep undergrowth blending into the cerulean blue of a summer sky. I was obsessed by the exquisite turn on the handle that rested so warm and smooth in my hand. I adored it. I felt part of the history of every person who had ever touched it and I often wept for the integrity of the artisan who made it. The glaze on this object mirrored 
my face and blinded me. I loved it, I loved it.... but now...well the object and I no longer have a relationship We are not even friends. This object and I can't communicate. We are estranged. It's better that way. I mean what can you say to an object like this? Nothing. There is nothing between us any more. Nothing to say because there is nothing there. Is there? Objectively.... from an objective point of view: absolutely nothing there. Would you agree? You would?

Now hold on a minute. Remember me? I could be lying, I could be pretending. Let's not get too carried away here. OK so I could never hold a tune, but let's not go straight for the negative scenario. Benefit of the doubt eh?

Glass - bottle, bottle - glass.

I'm quoting Tommy Cooper now you understand. Now you see it, now you don't, don't, don't. You don't see it? You don't see anything? Oh no! Then you can see I am without object? You perceive my lack of intent? I am stripped naked. Oh horror. I never thought it would come to this.... what am I to do? I must do something; I must be something...

I know, I' || become a desperate character. No that's wrong. My character will become desperate. Is she? Desperate? What the hell? Who the hell? I don't know. I must think. No I must feel.... my character. The desperation in my character. But I am a character. I am a character.

A desperate woman. Oh I am, I am.... desperate. I could do anything. I could be anything. I could be.... I could be.... female? Well obviously, an obvious female, a stereotype, I could be that, easy. Why not? A tart for instance - yes I could pop up a tart. An old pro. "Thirty, I'll do you a blow for thirty." Who's a drug addict. "Fifty for the full works, front or back." With a vicious pimp "Double it for any S and M." She's innocent really. "Two hundred with 
trimmings, costume, parafinalia. You'll like it, l' m pierced throughout." Viceless in her own completely corrupt way.

"Give us two fifty and you get the vid."

Yes, I could be a typical tart. I'd make a good stereotype. But stereo's out of date aint it? Well I bloody hope it is. All those dualities, dichotomies, dialectical binaries deconstructed - yeah - for good. It's not technology now it's technologies, it's digital, it's E mail. Fucking, faxing, factions, at a local level that is. Whilst somewhere else, over the rainbow, outa sight, it's global, megabytes, multi sensory, it's post-millennium, monumental, it's mythic. It's Medea.

Oh yes! Oh yes, Medea. Now there's a woman. And I could do that, what she did. I could kill my bloody children; I'd enjoy that. She was desperate - too right. I'm not that desperate, but I think about it sometimes, when they get on my nerves and if he's playing up Well her chap played her up proper - Old Jason. Yeah, he was a right bad lad. And she knew. And she decided.... And if they're all getting me down I think about my knife drawer. I count up the blades: serrated bread knife, meat cleaver. That steel carver with the bone handle. The old ones sharpen up best. Yeah she had intent - Old Medea. She had.... she had.... but...but I...but.... ....but I haven't. I'd just be pretending. Lying again. Pretending to pretend. But to be honest.... which I know is a contradiction in terms with me...but sometimes...I just feel...you can stick your cyberculture, your ontological insecurity, I just want...I just wish...sometimes...all the time actually...I do...just... Well I do miss Medea! I'm sorry about the tears, it's unlike me, but a rounded character must have its moments of doubt, cannot be without complexity or emotion. And I do, well, just then anyway.... I did feel...something. Psychology? Oh I wouldn't go so far as that. I couldn't generalise. The vagaries of my personality are more...well personal. More self-centred. 
Yes, that's me, just self, self, self. I admit it, I am selfish. Well, it's inevitable. After

all...there's only me, I'm the only one here, up here, getting looked at. I mean if someone else was with me, well, it'd be different. I wouldn't be so lonely for one thing. I wouldn't feel such a complete failure, so hurt and wounded. I am you know. I'm a tragically scarred figure. Lonely, confused, damaged by deceit. How can you laugh? I mean, what do you think this is? Oh, I wish I could escape.... from myself, from this body.....from this form... this formula.

Formula? Form - ula. Ula, ula? Sounds like part of my body, an intimate part. The ula.... just down from the ova. Hot, engorged and covered in feathers. Feathers for flying. Flying! Oh yes! Why did I give up flying? What for? For this misery? Not likely. I'd rather be battered by the winds of fate. I have wings. So I can fly away. I can escape, I must, you must help me. I just need a little lift, some audience participation. I mean why use wires when you can help? You want to? Well thank you. I'll come down and.... now.... now just stand perfectly still and perhaps bend your knees? Good, good. Then I can get up on your.... mind the wings.... don't damage the...careful! Up, higher, that's it, that's right. Now.... let go. Let me fly! Wheeeeeeeeeeeeeee! Ow!

See that? Did you see that? Yes well.... so much for... I should have known, I mean, I mean we're talking flying here, we're talking lift off, I mean, if weight ratio came into it a swan would never get off the ground and as for a pigeon....

But they do - they do fly. Don't they? Don't they?

We've all seen them haven't we - up there - suspended, despite our disbelief. We've seen them flying, haven't we?

Did you say yes? Oh praise the lottery! God bless supermarkets and all who shop in them! I feel light hearted again, more airy, more fit for flight. If I just open my wings again 
like this and stick in the feather you so kindly returned, I feel I might be able to, of my own volition, fly in the face of truth. Yes here I go, here I go..... up into the ether. Here I am spreading my wings and sallying forth against all reason. Like a will-o-the-wisp, like a shadow against the light. Because you know, deceit is so delicious, pretence is pure pleasure. Lies are - oh just loll out your tongue and lick up those lies. Come with me, believe me, believe in me, I know you do. I can feel you do. Oh yes, this is it, this is the moment, this is the place. Who needs a storyline, or an object? There is no crock of gold at the end of the rainbow, only me and yes, yes; it's true that.... if you truly, truly believe in me then I can. I will....

look I am flying! 